\title{
PENGGUNAAN BUKU PENUNJANG TEMATIK TERPADU BERBASIS KETERAMPILAN PROSES TEMA INDAHNYA KEBERSAMAAN UNTUK MENINGKATKAN KETERAMPILAN MEMBACA PEMAHAMAN SISWA KELAS IV SD
}

\author{
Rizka Nur Oktaviani ${ }^{1}$, Putri Kurnianingtyas ${ }^{2}$ \\ STKIP Bina Insan Mandiri ${ }^{1}$, STKIP Bina Insan Mandiri ${ }^{2}$ \\ Pos-el: rizkanuroktaviani@ stkipbim.ac.id ${ }^{1}$,putrikurnia@stkipbim.ac.id ${ }^{2}$
}

\begin{abstract}
ABSTRAK
Keterampilan membaca adalah salah satu keterampilan yang sangat diperlukan seseorang karena dengan membaca seseorang akan mendapatkan informasi atau pengetahuan yang baru. Salah satu jenis keterampilan membaca yang hraus dikuasai oleh siswa kelas IV SD adalah membaca pemahaman. Berdasarkan hasil observasi menunjukkan bahwa keterampilan membaca pemahaman masih rendah. Salah satu penyebab rendahnya keterampilan membaca pemahaman adalah kurangnya refrensi buku penunjang/buku pendamping buku teks K13. Tujuan dalam penelitian ini untuk mendeskripsikan penggunaan buku penunjang tematik terpadu berbasis keterampilan proses tema indahnya kebersamanan untuk meningkatkan keterampilan membaca pemahaman. Rancangan penelitian ini menggunaan penelitian tindakan kelas (PTK). Teknik dalam penelitian ini menggunakan teknik observasi dan tes. Adapun dalam teknik analisis data menggunakan deskriptif kualitatif dan kuantitatif. Hasil penelitan menunjukkan bahwa hasil keterlaksanaan aktivitas guru selama pembelajaran baik siklus I dan sikluas ke II memeroleh hasil persentase sebesar 100\%, sedangkan skor ketercapaian pelaksanaan peebelajaran pada siklus I memeroleh sebesar 72,45 dengan kriteria baik dan pada siklus ke II memeroleh sebesar 91,65 dengan kriteria amat baik. Sementara itu, hasil keterampilan membaca pemahaman pada siklus I memeroleh persentase sebesar $71,25 \%$ dan siklus II memeroleh persentase sebesar 93,56\%. Jadi dapat disimpulkan dengan menggunakan buku penunjang tematik terpadu tema indahnya kebersamaan dapat meningkatkan keterampilan membaca pemahaman siswa kelas IV SD Hidayatul Mubtadiin.
\end{abstract}

Kata Kunci: Buku Penunjang Tematik, Keterampilan Membaca.

\begin{abstract}
Reading skills are one of the skills that are needed by someone because with a reading someone will get new information or knowledge. One type of reading skills that must be mastered by fourth grade elementary school students is intensive reading. Based on the results of observations, it shows that intensive reading skills are still low. One of the reasons for the lack of reading comprehension skills is the lack of reference supporting books / textbook accompanying books K13. The aim this study is to describes the using of supporting books theme of the beauty of togetherness in improving reading comprehension skills. The design of this study uses classroom action research (CAR). The technique in this study uses observation techniques, and tests. As for the data analysis techniques using qualitative and quantitative descriptive. Research results show that the results of the implementation of teacher activities during learning both cycle I and cycle II get a percentage of 100\%, while the learning achievement score in cycle I obtained 72.45 with good criteria and the cycle in cycle II obtained 91, 65 with very good criteria. Meanwhile, the results of reading comprehension skills in the first cycle obtained a percentage of $71.25 \%$ and the second cycle obtained a percentage of 93.56\%. So it can be concluded by using integrated thematic books supporting theme the
\end{abstract}


beautiful of togetherness can improve reading skills of students in grade IV SD Hidayatul Mubtadiin.

Keywords: Thematic Support Books, Reading Skills.

\section{PENDAHULUAN}

Bahasa dapat difungsikan sebagai alat komunikasi untuk menyalurkan perumusan maksud seseorang, melahirkan perasaan sesoran dan dapat terciptanya kerjasama dengan orang lain. Pada dunia pendidikan, bahasa dapat digunakan sebagai sarana pembenagan kreativitas, sarana penajaman proses berpikir kritis dan kreatif. Pada hakikatnya pembelajaran Bahasa Indonesia memilki tujuan untuk menumbuhkan kemampuan dalam menggunakan pikiran dan perasaan dengan menggunakan Bahasa sesuai dengan kaidah. Pembelajaran Bahasa Indonesia di sekolah mencakup 4 aspek keterampilan yaitu menyimak, membaca, berbicara, dan menulis. Menurut Nurjamal, dkk. (2011:2), Keempat keterampilan tersebut pada dasarnya merupakan kesatuan yang lazim disebut catur tunggal keterampilan berbahasa atau empat serangkai keterampilan berbahasa.

Salah satu keterampilan yang harus dikuasai siswa yaitu keterampilan membaca. Hal ini dikarenakan sebagaian besar dalam kegiatan proses belajar mengajar di sekolah melibatkan keterampilan membaca. Untuk mengakses atau memeperoleh informasi yang baru dengan melakukan kegiatan membaca. Membaca merupakan suatu keterampilan yang bersifat apresiatif, rumit, dan kompleks (Tarigan, 2008:9). Sementara itu, Nurhadi (2015:9) menjelaskan bahawa memebaca merupakan hal yang sangat dibutuhkan bagai manusia yang ingin maju. Selain itu, Nurhadi (2010:130) mengungkapkan bahawa proses membaca terlibat berbagai faktor dari internal maupun eksternal. Faktor internal meliputi

intelegensi, minat, sikap, bakat, motivasi, tujuan membaca, dan sebagainya, sedangkan faktor eksternal meliputi sarana bacaan, tingkat keterbacaan, lingkungan, kebiasaan, dan tradisi membaca. Dengan kata lain, proses membaca membutuhkan aspek berpikir seperti mengingat, memahami, membandingkan, membedakan, menganilis dan mengorganisasi dalam menangkap makna bacaan secara utuh.

Somadoyo

menjelaskan bahwa membaca pemahaman memiliki tujuan untuk memahami isis bacaan dalam teks dengan kata lin untuk memrinci faktafakta, ide pokok, atau mendapatkan kesimpulan. Hal ini sesuai dengan kurikulum 2013 pada mata pelajaran Bahasa Indonesia kompetensi dasar yang harus dikuasai siswa adalah 3.1 dan 3.2 Dalam pembelajaran Bahasa Indonesia pada siswa kelas IV siswa harus mengusai keterampilan membaca pemahaman dalam memahami isi bacaan, menganalisis ide pokok dan gagasan pendukung dan mengaitkannnya dengan pengalaman-pengalaman yang dimiliki.

Berdasarkan hasil observasi di SD Hidayatul Mubtadiin Pasuruan menunjukkan bahwa $65 \%$ siswa belum mampu memahami isi bacaan dan membedakan gagasan pendukung dan gagasan utama. Hal ini disebabkan oleh beberapa faktor diantaranya guru hanya menyuruh salah satu siswa membaca teks ke depan dan siswa yang lain menyimak, sehingga membuat siswa merasa bosan dan malas membaca. Selain itu, kurangnya buku refrensi atau buku penunjang buku teks K13 untuk menjelaskan perbedaan gagasan utama dan gagasan pendukung, sehingga 
beberapa siswa masih mengalami kesuliatan dalam memahami isi bacaan atau membedakan dan menganalsis gagasan utama atau gagasan pendukung.

Berdasarkan latara belakang di atas, maka dilakukan penelitian sebagai upaya untuk memecahkan masalah yang dihadapi dengan berkolaborasi guru kelas dengan menggunakan rancangan penelitian tindakan kelas. Maka judul penelitian ini adalah "penggunaan buku penunjang terpadu tematik berbasis keterampilan proses tema indahnya kebersamaan untuk meningkatkan keterampilan membaca pemahaman siswa kelas IV SD Hidayatul Mubtadiin". Tujuan penelitian ini adalah untuk mengetahui peningkatan keterampilan membaca pemahaman dengan menggunakan buku penunjang tematik terpadu berbasis keterampilan proses.

Manfaat dalam penelitian ini adalah memberikan refrensi atau pilihan pustaka lain untuk menunjang pemebelajaran membaca pemahaman siswa. Bagi siswa diharapkan kemampuan siswa dalam membaca pemahaman dapat meningkat, bagi peneliti dapat berkolaborasi dengan guru sehingga membantu perbaikan dan peningkatan kualitas pembelajaran keterampilan membaca pemahaman di sekolah.

Buku dipakai sebagai sarana belajar dalam kegiatan pembelajaran di sekolah. Buku penunjang merupakan buku yang berfungsi sebagai pelengkap dari buku pokok atau buku utama. Buku penunjang termasuk tipe dari buku teks. Buku teks adalah buku standar/buku setiap cabang khusus studi dan dapat terdiri atas dua tipe, yaitu buku pokok/utama dan suplemen/tambahan (Lange dalam Tarigan, 2009:11). Tarigan (2009:12) menjelaskan bahwa buku penunjang adalah buku yang berfungsi sebagai bahan pengayaan bagi anak, baik yang berhubungan dengan pelajaran maupun yang tidak berhubungan dengan pelajaran. Sementara itu, menurut Muslich (2010:37), buku teks sebagai penunjang pelaksanaan kegiatan pembelajaran di kelas dikelompokkan menjadi dua yaitu buku teks wajib dan buku teks penunjang (buku pelengkap). Berdasarkan beberapa uraian di atas, maka dapat disimpulkan bahwa buku penunjang adalah buku tambahan untuk melengkapi buku pelajaran yang membantu siswa untuk mencapai tujuan pembelajaran yang diharapkan, yang disusun secara sistematis berdasarkan perkembangan dan kebutuhan peserta didik. Buku penunjang berbasis keterampilan proses merupakan buku yang disusun berdasarkan aspek-aspek keterampilan proses. Aspek-aspek tersebut terdiri dari: mengamati, mengajukan pertanyaan, mengklasifikasikan, mengukur, dan memrediksi.

Buku penunjang tematik SD berbasis keterampilan proses adalah buku penunjang tematik yang memuat keterampilan intelektual yang menyangkut proses ilmiah atau cara kerja untuk memperoleh hasil atau produk. Selain itu, buku penunjang tematik SD berbasis keterampilan proses ini dapat dugunakan untuk mengurangi ketergantungan siswa terhadap guru, memberikan pengalaman pembelajaran secara langsung, dapat menjadi wahana bagi siswa untuk mempelajari diri sendiri dan alam sekitar, serta dapat diterapkan secara mandiri oleh siswa untuk memecahkan permasalahan yang dijumpainya dalam kehidupan seharihari.

\section{METODE PENELITIAN}

Penelitian ini menggunakan rancangan peneltian tindakan kelas (PTK). Aqib (2011;13) menjelaskan bahwa penelitian tindakan kelas adalah penelitian yang dilakukan oleh guru kelas melalui refleksi dir yan bertujuan untuk memperbaiki kinerjanya sehingga 
hasil belajar siswa meningkat. Subjek penelitian ini adalah guru dan siswa kelas IV, sedangkan lokasi penelitiani di SD Hidayatul Mubtadiin Pasuruan. Pelaksanaan penelitian ini direncanakan dalam dua siklus dengan alokasi waktu $3 \times 35$ menit. Dari setiap siklus terdiri atas 3 tahapan, antara lain: (1) perencanaan, (2) perlakuan dan pengamatan (observasi), (3) refleksi (reflecting) (Kemmis dan Mc Taggart dalam Arikunto, 2006:92). Tahap-tahap dalam siklus PTK menurut Kemmis dan Taggart digambarkan dalam bagan sebagai berikut:

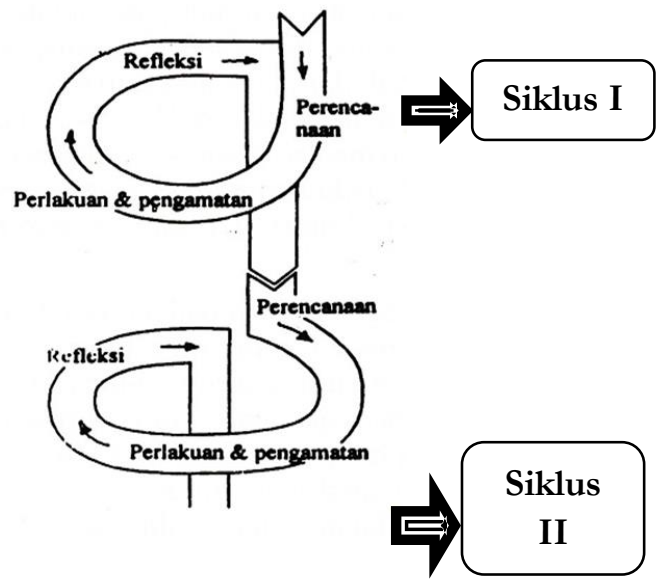

Gambar 2.1

Alur siklus PTK menurut Kemmis dan Taggart (dalam Arikunto, 2006:93)

Adapun prosedur yang digunakan dalam penelitian ini dengan tahapan setiap siklusnya sebagai berikut: 1) perencanaan; 2) pelaksanaan tindakan dan observasi; 3) refleksi. Pada tahap tahap perencanaan peneliti melakukan kegiatan diantaranya: 1) menganalisis kurikulum 2013 kelas IV SD yang disesuaikan dengan permasalahan; 2) merancang RPP tema indahnya kebersamaan pembelajaran pertama; 3) menyusun instrument penelitian berupa lembar observasi aktivitas guru, lembar tes, dan lembar cacatan lapangan; 4) menyiapkan media pemebelajaran, dan 5) menyiapkan indikator pembelajaran.

Sementara itu, pada tahap pelaksanaan tindakan dan observasi.
Pada tahap ini merupakan tahapan awal dalam menerapkan rancangan yan telah dibuat yaitu pelaksaan tindakan berupa pembelajaran membaca pemahaman dengan menggunakan buku tematik terpadu berbasis keterampilan proses, dan pelaksanaan tindakan dirancang dengan menggunakan siklus yang berulang jika siklus kedua belum berhasil. Selain itu, pada tahap observasi dilakukan oleh peneliti untuk mengamati guru kelas IV SD Hidayatul Mubtadiin secara intensif dan menyeluruh terkait pelaksanaan aktivitas pemebelajaran membaca pemahaman dari awal hingga akhir.

Tahapan-tahapan dalam setiap siklus diakhiri dengan kegiatan merefleksi. Tahapan ini dilakukan untuk mengmukakan kembali yang sudah dilakukan dan melakukan penyampaian serta membahas hasil pengamatan yang belum terlaksana atau tercapai dari hasil analisis data. Adapun Teknik dalam penelitian ini berupa observasi dan tes. Instrument pengumpulan data berpa lembar observasi dan lembar tes membaca pemahaman. Teknik analisis data penelitian ini dengan cara deskriptif kualitatif dan kuantitatif. Adapun Teknik deskriptif kualitaif meliputi beberapa tahapan yaitu, pengumpulan data, reduksi data, dan penyimpulan data, sedangkan Teknik analisis deskriptif kuantitatif meliputi tahapan mengalisis data hasil observasi dan data tes membaca pemahaman.

Kriteria indicator keberhasilan dalam penelitian ini ada 3 yaitu: keterlaksanaan aktivitas guru dalam pembelajaran membaca pemahaman dengan menggunakan buku penunjang tematik terpadu tema indahnya kebersamaan yaitu $\geq 80 \%$ (Aqib, dkk., 2011:41), (b) ketercapaian pelaksanaan pembelajaran $\geq 80$ (Aqib, dkk., 2011:41), (c) Pembelajaran dianggap tuntas apabila > 75\% siswa mendapat nilai $\geq$ KKM yang ditetapkan, yaitu 70 (Djamarah dan Zain, 2010:107). 


\section{HASIL DAN PEMBAHASAN Hasil Penelitian}

Hasil penelitian pelaksanan pemebelajaran memebca pemahaman dengan menggunakan buku penujang tematik terpadu tema indahnya kebersamaan dipaparkan berdasarkan tahapan dalam setiap siklus PTK yaitu tahaan perencanaan, tahapan pelaksanaan tindakan dan observasi, tahapan refleksi. Pada tahapan perencanan baik siklus I dan siklus II peneliti merencanakan persiapan untuk melaksanakan proses pembelajaran dengan rincian sebagai berikut: 1) menganalisis KI dan KD kurikulum 2013 mata pelajaran bahasa Indonesia kelas IV semester 1 Tema 1 pemebelajaran ke-2; 2) merancang perangakat pembelajaran tentang materi membaca pemahaman mencakup pengembangan: Silabus, RPP (Recana Pelaksanaan Pembelajaran), Lembar Kerja Siswa (LKS) dan Lembar Kegiatan Peserta Didik(LKPD); 3) menyusun instrumen penelitian yaitu berupa lembar observasi aktivitas guru, dan lembar tes keterampilan membaca pemahaman, 4) menyiapkan media pembelajaran yang berupa media; 5) menyusun indikator keberhasilan yang sudah ditentukan sebelumnya, dan 6) menentukan jadwal pelaksanaan tindakan. Adapun jadwal pelaksanaan tindakan pada siklus I yaitu 29 Juli 2019 dan siklus II pada tanggal 01 Agustus 2019.

\section{Pembahasan}

Berdasarkan hasil analisis observasi aktivitas keterlaksanaan dan ketercapaian guru serta hasil tes keterampilan membaca pemahaman dengan menggunakan buku penunjang tematik terpadu berbasis keterampilan proses dapat dilihat pada tabel di bawah ini:

Tabel 3.1

Hasil Observasi Akltivitas Guru dan Hasil Tes Keteramapilan Membaca Pemahaman dengan Menggunakan Buku Penunjang

Tematik Terpadu Berbasis Keterampilan Proses pada Siklus I dan Siklus II

\begin{tabular}{|c|c|c|c|c|}
\hline No & Data & Siklus I & $\begin{array}{c}\text { Siklus } \\
\text { II }\end{array}$ & $\begin{array}{c}\text { Pening- } \\
\text { katan }\end{array}$ \\
\hline 1. & $\begin{array}{c}\text { Keterlak- } \\
\text { sanaan } \\
\text { Aktivitas } \\
\text { guru }\end{array}$ & $100 \%$ & $100 \%$ & - \\
\hline 2. & $\begin{array}{c}\text { Keterca- } \\
\text { paian } \\
\text { aktivitas } \\
\text { guru }\end{array}$ & 72,45 & 91,65 & 19,20 \\
\hline 3. & $\begin{array}{c}\text { Hasil } \\
\text { Belajar } \\
\text { Siswa }\end{array}$ & 74,56 & 84,59 & 10,03 \\
\hline 4. & $\begin{array}{c}\text { Ketunta- } \\
\text { san } \\
\text { klasikan } \\
\text { hasil } \\
\text { belajar } \\
\text { siswa }\end{array}$ & $71,25 \%$ & 93,56 & $22,31 \%$ \\
$\%$ & & & \\
\hline
\end{tabular}

Adapun tahapan pelaksanaan tindakan dan observasi aktivitas guru pada siklus I dan siklus II dalam proses pembelajaran dilakukan oleh 2 pengamat yaitu peneliti dan teman sejawat. Kegiatan observasi dilakuan bersamaan dengan proses pemebelajaran berlangsung. Pada siklus I dan siklus II masing-masing hasil keterlaksanan persentase aktivitas guru memeroleh $100 \%$, sedangkan hasil ketercapaian aktivitas guru pada siklus I memeroleh sebesar 72,45 dengan kriteria baik dan berhasil tetapi perlu adanya perbaikan karena terdapat beberapa aspek belum terlaksna dengan baik seperti yang telah direncanakan. Pada siklus ke II hasil ketercapaian observasi aktivitas guru memeroleh 91,65. Hal tersebut sesuai dengan pendapat (Djamarah, 2005:263 yang menyatakan bahwa tingkat ketercapaian aktivitas guru dikatakan amat baik dan berhasil apabila mendapat $\geq 80$

Rata-rata hasil tes keterampilan membaca pemahaman pada siklus I memeroleh nilai yaitu 74,56 dengan siswa yang mendapat nilai $\geq 70$ sebanyak 17 siswa dan persentase ketuntasan hasil belajar siswa sebesar 
71,25\%. Persentase tersebut jika dikualifikasikan pada ketuntasan hasil belajar siswa, maka ketuntasan hasil belajar siswa cukup namun belum mencapai target peneliti yaitu ketuntasan hasil belajar $\geq 75 \%$ sehingga diperlukannya siklus II. Berdasarkan nilai rata-rata hasil tes keterampilan membaca pemahaman pada siklus II yaitu 84,59 dengan siswa yang mendapat nilai $\geq 70$ sebanyak 23 siswa dan persentase ketuntasan hasil belajar siswa sebesar yang memeroleh persentase sebesar 93,56\%.

Hasil refleksi yang dilakukan guru Bersama obsever pada siklus I menunjukkan bahwa guru dalam menjelaskan materi peebelajaran kurang jelas, suara guru kurang keras, dan tidak memerhatikan waktu. Oleh karena itu kegiatan pemebelajaran belum terlaksana secara maksimal. Setelah adanya perbaikan pada siklus ke II maka terlihat adanya peningkatan skor pada ketercapaian aktivitas pelaksanaan pembelajaran sebesar 19, 20 hal ini sudah mencapai kriteria keberhasilan pembelajaran yaitu $\geq 80$ dari seluruh aktivitas guru. Sementara itu, peningkatan nilai rata-rata hasil tes keterampilan membaca pemahaman pada siklus I dan siklus II sebesar 10,03 sedangan peningkatan persentase ketuntasan klasikal yaitu $22,31 \%$. Oleh karena itu, dengan menggunakan buku penunjang tematik terpadu tema indahnya kebersamaan berbasis keterampilan proses dapat meningkatkan keterampilan membaca pemahaman.

\section{SIMPULAN}

Berdasarkan simpulan di atas, maka peneliti menyarankan kepada guru, sekolah, dan peneliti lain. Adapun kepada guru hendaknya menggunakan buku penunjang tematik terpadu tema indahnya kebersamaan untuk dijadikan pendamping buku teks K13 pada pembelajaran membaca pemahaman sehingga dapat menciptakan pembelajaran yang aktif dan meyenangkan. Dalam menganlisis gagasan utama dan gagasan uatama hendaknya disertai contoh atau kata kunci yang membedakan gagasan utama dan pendukung, sehingga mempermudah siswa dalam kegiatan menganalisis atau membedakan isi atau gagasan utama dan pendukung.

Untuk pihak sekolah, peneliti menyarankan hendaknya dijadikan pemikiran yang positif dan juga dapat dijadikan bahan pustaka/refrensi untuk memotivasi para guru untuk menggunakan buku penunjang tematik terpadu tema indahnya kebersamaan berbasis keterampilan proses yang dapat meningkatkan keterampilan dalam pembelajaran membaca pemahaman teks. Sementara itu, pada pihak peneliti lain hendaknya dapat dijadikan acuan dan pemikiran positif untuk dilakukan penelitian selanjutnya.

\section{DAFTAR PUSTAKA}

Aqib, Zainal. (2006). Penelitian Tindakan Kelas untuk Guru. Bandung: Yrama Widya

Aqib Zainal, dkk. (2011). Penelitian Tindakan Kelas untuk Guru SD, SLB dan TK. Bandung: Yrama Widya

Arikunto, Suharsimi. (2006). Prosedur

Penelitian Suatu Pendekatan Praktik. Jakarta: Rineka Cipta

Nurhadi. (2005). Bagaimana Meningkatkan Kemampuan Membaca?: Suatu Teknik Memahami Literature yang Efisien. Bandung: Sinar Baru Algesindo.

Nurhadi. (2005). Membaca Cepat dan Efektif. Bandung: Sinar Baru Algensindo.

Nurjamal, Daeng. dkk. (2011). Terampil Berbahasa. Bandung: Alfabeta.

Muslich, Masnur. (2013). Pendidikan Karakter (Menjawab Tantangan Krisis Multidimensional). Yogyakarta: 
Ar-Ruzz Media

Somadayo. (2011). Strategi dan Teknik

Pembelajaran Membaca.

Yogyakarta: Pustaka Utama

Tarigan, Henry Guntur. (2008).

Membaca Sebagai Suatu

Keterampilan Berbahasa.

Bandung: Angkasa.

Tarigan, Henry Guntur. (2009). Telaah

Buku Teks Bahasa Indonesia.

Bandung: Angkasa 